\title{
Mutational status of K-ras and TP53 genes in primary sarcomas of the heart
}

\author{
JM Garcia', R Gonzalez'1, JM Silva', G Dominguez'1, IS Vegazo², C Gamallo³, M Provencio'1, P España1 and F Bonilla' \\ Departments of ${ }^{1}$ Medical Oncology and ${ }^{2}$ Pathology, Clinica Puerta de Hierro, 28035-Madrid, Spain; ${ }^{3}$ Department of Pathology, Hospital La Paz, \\ 28034-Madrid, Spain
}

Summary We investigated three patients with cardiac angiosarcomas and two with cardiac rhabdomyosarcomas, all for mutations at exons $5,6,7$ and 8 of the p53 gene and at exon 1 of K-ras. No point mutations were observed in the p53 gene in any of the five cases; however, at exon 1 of $\mathrm{K}$-ras, three patients $(60 \%)$ presented the same mutation at the first base of codon 13 ( $\mathrm{G}$ to $\mathrm{A}$ transition). Interestingly, this mutation was detected in both rhabdomyosarcoma and angiosarcoma histologic sarcoma types. (C 2000 Cancer Research Campaign

Keywords: cardiac sarcomas; K-ras mutations; TP53 mutations

Primary tumours of the heart have an incidence of only $0.001-0.28 \%$ (McAllister and Fenoglio, 1978). Of these, approximately $25 \%$ are sarcomas occurring in adults (Silverman, 1980). Angiosarcomas and rhabdomyosarcomas are the most frequent histological subtypes (Putnam et al, 1991). In general, the survival of these patients is short (Molina et al, 1990; Putnam et al, 1991; Burke et al, 1992) despite complete surgical resection by heart transplantation (Crespo et al, 1993).

The molecular characterization of primary cardiac sarcomas with respect to genetic alterations in p53 and K-ras genes has not been widely studies. However, there is some evidence of the presence of p53 and K-ras gene alterations in sarcomas located in other organs (Muligan et al, 1990). A number of reports dealing with the occurrence of $p 53$ gene mutations in sarcomas show it to be a frequent event, especially in the rhabdomyosarcoma histologic subtype (Felix et al, 1992; Wurl et al, 1996; Kusufuka et al, 1997). Specifically, Naka et al (1997) reported two cases of $p 53$ gene mutations in four patients with primary cardiac angiosarcomas.

Different mutation rates of ras genes have been detected in sarcomas. K-ras mutations in $26 \%$ of hepatic angiosarcomas (Przygodzki et al, 1997), point H-ras mutations in 33\% of rhabdomyosarcomas and malignant fibrous histiocytomas (Wilke et al, 1993), and N-ras and K-ras mutations in 35\% of rhabdomyosarcomas (Stratton et al, 1989). However, genetic studies of heart sarcomas have not been reported.

We investigated the mutational status of $p 53$ and $\mathrm{K}$-ras genes in primary cardiac sarcomas in a small number of patients.

Received 24 May 1999

Revised 6 October 1999

Accepted 24 November 1999

Correspondence to: F Bonilla, Molecular Genetics Unit, Clinica de Trabajo, Avd. de la Reina Victoria 21, 28003-Madrid, Spain

\section{MATERIALS AND METHODS}

\section{Tumour samples and DNA extraction}

We obtained tumour specimens from seven patients in two Madrid hospitals. Five samples corresponded to sarcomas (three angiosarcomas and two rhabdomyosarcomas) with two additional samples corresponding to rhabdomyomas being taken from infants who died of multiple cardiac rhabdomyomas 3 and 7 days after birth. All the histological specimens were fixed in $10 \%$ formalin and routinely processed by paraffin-embedding. Histologic confirmation of the diagnosis was performed prior to the molecular study. DNA was extracted from formalin-fixed, paraffin-embedded tissues using chelating resin. Paraffin blocks without samples were used as negative controls for each polymerase chain reaction (PCR) analysis throughout the procedure.

\section{Mutational study of the $p 53$ gene}

To establish the presence of point mutations in the conserved exons of TP53, polymerase chain reaction/single-strand conformation polymorphism (PCR-SSCP) analysis was performed. Exons $5,6,7$ and 8 of the $p 53$ gene were amplified. PCR was performed under standard conditions in a $25-\mu$ l volume containing $2-\mu 1$ (100 ng) tumour DNA template; $2.5-\mu 1$ of $10 \times$ PCR buffer and 1.5 U of Ampli Taq Gold (Perkin-Elmer, Roche Molecular Systems Inc., Branchburg, NJ, USA); $200 \mu \mathrm{M}$ deoxynucleotide triphosphate (dNTP) mix; $0.6 \mu \mathrm{M}$ of each primer; and various concentrations of magnesium chloride $\left(\mathrm{MgCl}_{2}\right)$ depending on the primer and distilled water $\left(\mathrm{H}_{2} \mathrm{O}\right)$ needed to reach the total volume. For PCR amplification, the samples underwent 40 cycles at $94^{\circ} \mathrm{C}$ for $1 \mathrm{~min}$, followed by subjection to different annealing temperatures depending on the primer, and $70^{\circ} \mathrm{C}$ for $1 \mathrm{~min}$. The amplified products were denatured by mixing with $15 \mu \mathrm{l}$ of denaturing stop solution that contained $98 \%$ formamide, $10 \mathrm{ml} \mathrm{l}^{-1}$ edathamil ( $\mathrm{pH} \mathrm{8.0)}$, $0.02 \%$ xylene cyanol and $0.02 \%$ bromophenol blue, being heated to $95^{\circ} \mathrm{C}$ for $5 \mathrm{~min}$ and rapidly cooled on ice. Electrophoresis was 
Table 1 Molecular and clinicopathologic patients characteristics

\begin{tabular}{lllllccccc}
\hline Age & Sex & Histology & Chamber & Treatment & $\begin{array}{c}\text { Postsurg. } \\
\text { ChT }\end{array}$ & $\begin{array}{c}\text { Survival } \\
\text { (months) }\end{array}$ & Status & $\begin{array}{c}\text { p53 gene } \\
\text { Mut }\end{array}$ & $\begin{array}{c}\text { K-ras } \\
\text { Mut }\end{array}$ \\
\hline 54 & F & Angio & RA & No specific & No & 5 & D & No & No \\
27 & M & Rhabdo & LA & Resection & ADM & 7 & D & No & Yes \\
31 & M & Angio & RA & Transpl & ADM & 10 & D & No & Yes \\
36 & M & Angio & RA & Transpl & ADM & 8 & D & No & Yes \\
52 & F & Rhabdo & LV & Transpl & ADM & 45 & D & No & No \\
\hline
\end{tabular}

F, female; M, male; Angio, angiosarcoma; Rhabdo, rhabdomyosarcoma; RA, right atrium, LA, left atrium: LV, left ventricle; Transpl, heart transplantation; D, dead; Mut, mutations; ADM, doxorubicin; ChT, chemotherapy.

run on non-denaturing $8-12 \%$ polyacrylamide gels for $12-15 \mathrm{~h}$ at $250 \mathrm{~V}$. The allelic band intensity on the gels was detected by nonradioisotopic means using a commercially available silver staining method (Oto et al, 1993). All specimens that showed a differential band at SSCP were amplified to obtain templates for DNA sequencing. These amplifications were independent to those used for SSCP analysis. Amplified DNA fragments were purified from $0.9 \%$ agarose gels using the Geneclean Kit (Bio-101, Inc., La Jolla, CA, USA) and used for direct DNA sequencing by the ddNTP method with the Sequenase Kit (United States Biochemical Corp. Cleveland, OH, USA).

\section{Mutational analysis of K-ras gene}

PCR amplification of K-ras gene, using $100 \mathrm{ng}$ genomic DNA as template, was carried out in a $25-\mu 1$ reaction volume with a final concentration of $1 \times$ PCR buffer and 1.5 units of Ampli Taq DNA polymerase (Perkin-Elmer, Roche Molecular Systems Inc., Branchburg, NJ, USA); $200 \mu \mathrm{M}$ dNTP mix; $0.6 \mu \mathrm{M}$ of each primer; $2.5 \mathrm{mM} \mathrm{MgCl}_{2}$ and distilled $\mathrm{H}_{2} \mathrm{O}$ to reach the total volumes. For amplification, each sample was denatured at $94^{\circ} \mathrm{C}$ for $5 \mathrm{~min}$ and subjected to 35 cycles $\left(94^{\circ} \mathrm{C}\right.$ for $30 \mathrm{~s}, 58^{\circ} \mathrm{C}$ for $40 \mathrm{~s}$ and $72^{\circ} \mathrm{C}$ for $30 \mathrm{~s}$, followed by a final $7-\mathrm{min}$ extension at $72^{\circ} \mathrm{C}$ ). The amplified products were mixed with $20 \mu \mathrm{l}$ denaturing stop solution that contained $98 \%$ formamide, $10 \mathrm{mml} \mathrm{1}^{-1}$ edathamil $(\mathrm{pH} 8.0), 0.02 \%$ xylene cyanol and $0.02 \%$ bromophenol blue, heated to $95^{\circ} \mathrm{C}$ for $5 \mathrm{~min}$ and rapidly cooled on ice. The samples were electrophoresed on non-denaturing $12 \%$ polyacrylamide gels at $250 \mathrm{~V}$ overnight at room temperature. Products were visualized by nonradioisotopic means using a commercially available silver staining method (Oto et al, 1993). Primers used for amplification of exon 1 of K-ras, which contains codons 12 and 13, were: 5'-GACTGAATATAAACTTGTGGTAGT and 5'-CTATTGTTGGATCATATTCGTCC. All specimens, with and without differential bands at SSCP, were sequenced following the same method as used in the sequencing process of $p 53$ gene.

\section{RESULTS}

The clinicopathologic characteristics of the patients and treatments administered are listed in Table 1.

The five cardiac sarcomas were screened for mutations by PCRSSCP and direct sequencing at exons 5, 6, 7 and 8 of the $p 53$ gene and exon 1 of the K-ras gene. SSCP analysis of the exons of the p53 gene did not reveal any cases of bands with altered electrophoretic mobility. Considering that SSCP sensitivity is low under certain circumstances (Hayashi, 1991) direct sequence

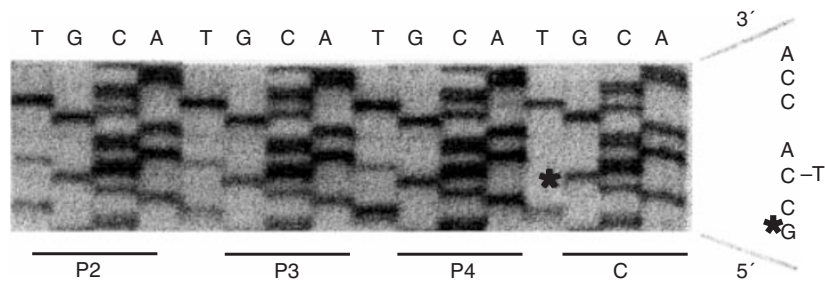

Figure 1 Sequencing analysis of patients $\mathrm{P} 2, \mathrm{P} 3$ and $\mathrm{P} 4$ shows a nucleotide change ( $C$ to $T$ ) in the reverse sequence that corresponds to a transition ( $G$ to $A$ ) of the K-ras gene. This transition at codon 13 causes an amino acid change (Gly-Ser). The change was not observed in the DNA of the control case $(\mathrm{C})$

analysis for exons 5, 6, 7 and 8 of the $p 53$ gene in each case were performed and no point mutations were detected. The first exon of K-ras was checked by SSCP in all lesions and three sarcomas showed a mobility shift; however, to avoid false-negatives, direct sequence analysis was performed in all cases. Mutations at codon 13 of K-ras were present in all three cases that displayed changes in mobility. G to A transition at the first base of codon 13, which resulted in one amino acid substitution (Gly-13 to Ser) (Figure 1), was detected in two angiosarcomas and one rhabdomyosarcoma.

Although our series does not permit a statistical study due to its small size, in terms of clinicopathologic features, the three patients with K-ras mutations were under 50 years of age (mean 31 years) and the two patients without K-ras mutations were over 50. Moreover, it is noteworthy that the same K-ras mutation was present in both rhabdomyosarcoma and angiosarcoma.

\section{DIscussion}

The rare occurrence of primary cardiac sarcomas may explain the almost complete absence of molecular studies involving the molecular status of $p 53$ and $\mathrm{K}$-ras genes in these tumours. To the best of our knowledge, there have been no reports dealing with mutations in the ras gene family, and there is only one report of a study examining p53 gene mutations in cardiac angiosarcomas with point mutations being found in 50\% of cases (Naka et al, 1997). No point mutations in the $p 53$ gene were detected in the cases we present here, suggesting that it is difficult to draw conclusions about $p 53$ inactivation in these rare tumours from small series.

However, the current study shows that K-ras gene mutations could be relatively frequent in these rare tumours. Of the five cases studied, we found a mutation at the first position of codon 13 (Gly-13 to Ser) in three sarcomas, two angiosarcomas and one rhabdomyosarcoma, while no mutations were observed in the two cardiac rhabdomyomas assessed. Although the implication of the 
ras oncogene family in the development of mesenchymal tumours was reported long ago (Stratton et al, 1989) there were no studies available concerning the presence of these point mutations in sarcomas derived from heart tissue.

As was mentioned above, the clinicopathologic features of our patients were similar to those reported elsewhere with respect to age, tumour location and histological type. In our series, it is interesting to note that the same mutation was observed in both a heart rhabdomyosarcoma and an angiosarcoma.

In conclusion, we report a small series of heart sarcomas subjected to a specific molecular study that shows the presence of K-ras mutations at codon 13. Nevertheless, there were no differential clinical characteristics except for the patients harbouring these mutations being younger and predilection for the male sex.

\section{ACKNOWLEDGEMENTS}

We are indebted to Mrs M Messman and Mr M Hadley-Adams for the revision and preparation of the manuscript. This work was supported by grants from the Fundación Caja Madrid and BristolMyers, S.A.

\section{REFERENCES}

Burke AP, Cowan D and Virmani R (1992) Primary sarcomas of the heart. Cancer 69: $387-395$

Crespo MG, Pulpon LA, Pradas G, Serrano S, Segovia J, Vegazo I, Salas C, España P, Silva L and Burgos R (1993) Heart transplantation for cardiac angiosarcoma: should its indication be questioned? J Heart Lung Transplant 12: $527-530$
Felix CA, Kappel CC, Mitsudomi T, Nau MM, Tsokos M, Crouch GD, Nisen PD, Winick NJ and Helman LJ (1992) Frequency and diversity of p53 mutations in childhood rhabdomyosarcoma. Cancer Res 52: 2243-2247

Hayashi K (1991) PCR-SSCP: a simple and sensitive method for detection of mutations in the genomic DNA. PCR Methods Appl 1: 34-38

Kusafuka T, Fukuzawa M, Oue T, Komoto Y, Yoneda A and Okada A (1997) Mutation analysis of p53 gene in childhood malignant solid tumors. J Pediatr Surg 32: 1175-1180

McAllister HA and Fenoglio JJ (1978) Tumors of the cardiovascular system. In: Atlas of Tumor Pathology, vol. 15, pp. 73-119. Washington DC: Armed Forces Institute of Pathology

Molina JE, Edwards JE and Ward HB (1990) Primary cardiac tumors: experience at the University of Minnesota. J Thorac Cardiovasc Surg 38: 183-191

Mulligan LM, Matlashewski GJ, Scrable HJ and Cavenee WK (1990) Mechanism of p53 loss in human sarcomas. Proc Natl Acad Sci USA 87: 5863-5867

Naka M, Tomita Y, Nakanishi H, Araki N, Hongyo T, Ochi T and Aozasa K (1997) Mutations of $p 53$ tumor-suppressor gene in angiosarcoma. Int J Cancer $\mathbf{7 1}$ 952-955

Oto M, Miyake S and Yuasa Y (1993) Optimization of nonradioisotopic single strand conformation polymorphism analysis with a conventional minislab gel electrophoresis apparatus. Anal Biochem 213: 19-22

Przygodzki RM, Finkelstein SD, Keohavong P, Zhu D, Bakker A, Swalsky PA, Soini Y, Ishak KG and Bennett WP (1997) Sporadic and thorotrast-induced angiosarcomas of the liver manifest frequent and multiple point mutations in K-ras-2. Lab Invest 76: 153-159

Putnam JB, Sweeney MS, Colon R, Lanza LA, Frazier OH and Cooley D (1991) Primary cardiac sarcomas. Ann Thorac Surg 51: 906-910

Silverman NA (1980) Primary cardiac tumors. Ann Surg 191: 127-138

Stratton MR, Fisher C, Gusterson BA and Cooper CS (1989) Detection of point mutations in N-ras and K-ras genes of human embryonal rhabdomyosarcomas using oligonucleotide probes and the polymerase chain reaction. Cancer Res 49: $6324-6327$

Wilke W, Maillet M and Robinson R (1993) H-ras-1 point mutations in soft tissue sarcomas. Mod Pathol 6: 129-132

Wurl P, Taubert H, Bache M, Kroll J, Meye A, Berger D, Siermann A, Holzhausen HJ, Hinze R, Schmidt H and Rath FW (1996) Frequent occurrence of p53 mutations in rhabdomyosarcoma and leiomyosarcoma, but not in fibrosarcoma and malignant neural tumors. Int J Cancer 69: 317-323 